NBER WORKING PAPER SERIES

FISCAL POLICY AND INFLATION:

PONDERING THE IMPONDERABLES

\author{
Eric M. Leeper \\ Working Paper 9506 \\ http://www.nber.org/papers/w9506 \\ NATIONAL BUREAU OF ECONOMIC RESEARCH \\ 1050 Massachusetts Avenue \\ Cambridge, MA 02138 \\ February 2003
}

The views expressed herein are those of the author and not necessarily those of the National Bureau of Economic Research.

(C)2003 by Eric M. Leeper. All rights reserved. Short sections of text not to exceed two paragraphs, may be quoted without explicit permission provided that full credit including notice, is given to the source. 
Fiscal Policy and Inflation: Pondering the Imponderables

Eric M. Leeper

NBER Working Paper No. 9506

February 2003

JEL No. E310, E620, E630

\begin{abstract}
$\underline{\text { ABSTRACT }}$
An asset-pricing perspective on inflation reveals that it depends on current and expected monetary and fiscal policies. There are three ways to carry $\$ 1$ today into the future: money, bonds, and real assets. That dollar's purchasing power varies inversely with the price level. Expected money growth, tax rates, and government spending directly impinge on these expected rates of return of these assets, and determine the price level and the inflation rate. The paper considers a tax reduction that is financed by new government debt. It examines how alternative responses of current and future policies to the tax cut can imply very different outcomes for inflation.
\end{abstract}

Eric M. Leeper

Indiana University

Department of Economics

105 Wylie Hall

Bloomington, IN 47405

and NBER

eleeper@indiana.edu 


\title{
Fiscal Policy and Inflation: Pondering the Imponderables
}

\author{
Eric M. Leeper*
}

In July 2001, Congress approved President Bush's across-the-board tax cut, to be phased in over a 10-year period. The legislation includes a sunset provision that returns tax rates in 2011 to their original levels. How is this tax law likely to affect inflation over the next five years?

This practical question has a very complex answer - an answer that depends on the answers to a multitude of auxiliary questions: What if an economic downturn forces the tax cut to be deficit-financed by the selling of new government bonds? Are tax rates really going to return to their pre-tax cut levels in 2011? How will increases in government spending on homeland security or an expensive war in the Middle East complicate matters? If a new Federal Reserve chairman takes over from Alan Greenspan, how do the impacts of the tax cut change?

President Bush's supplementary $\$ 670$ million “growth and jobs" plan, which he proposed in January 2003, further complicates the analysis.

The auxiliary questions and many others one might contemplate highlight that the ultimate inflation effects of a tax cut can turn on consumers' and investors' beliefs about policies in the future. Those beliefs determine rates of return on assets today, affecting today's savings and investment decisions, which determine the inflation rate.

This paper offers an asset-pricing perspective on how fiscal policies affect inflation. That perspective has important differences from conventional views.

Conventional Keynesian thinking about macro policy focuses on the impacts of current government spending, tax, and interest rate policies on employment, personal income, and aggregate demand. Impacts on inflation depend on where the economy is operating relative to potential output. If the economy is at or near potential, a stimulus to demand raises inflation through the usual Phillips curve mechanisms. If resource utilization is slack, however, the inflationary consequences are benign. This thinking underlies nearly all reporting in the financial press about macro policies.

\footnotetext{
* Prepared for The Institute for Quantitative Research in Finance (The Q Group) Seminar, October 6-9, 2002. I thank David Gordon, Susan Monaco, Jennifer Roush, Jack Treynor, and Peter Williamson for helpful suggestions.
} 
This conventional description of macro policies is incomplete in ways that should disturb individuals making investment plans: it is silent on how policy behaves in the future. Yet current fiscal choices are necessarily linked to future fiscal decisions. Any change in policy today that alters the real value of debt held by the public must bring forth changes in future policies to support the new value of debt. For example, if a tax cut today is financed by new debt issuances, investors will buy the new bonds only if they expect the government will meet interest payments on the debt. But higher debt service requires either increases in revenues or decreases in other kinds of government spending. Whatever adjustment in policy investors expect will affect relative rates of return on assets and therefore portfolio choices and prices, including inflation. Standard descriptions are incomplete because they include no explicit statement of how future policies are likely to adjust.

To complete the description of the inflation consequences of current policies, one must decide how likely are the various possible reactions of future policies to the resulting changes in level of government liabilities. This is a difficult task. The range, timing, and likelihood of future policies depend on imponderables like the political and economic environments that will prevail in the future. Will Americans tolerate tax increases better in the $21^{\text {st }}$ century than they have the past 20 years? Will geopolitical realities call for higher or lower expenditures on national security? Will the persistent imbalances in social security get resolved through higher taxes, lower benefits, or some other creative policy? Pondering these imponderables is essential to predicting the impacts of fiscal policy on inflation now and in the future.

Over the past 30 years, the conventional static perspective on policy has been extended to include an intertemporal dimension, often with surprising results. Barro (1974) showed that if individuals rationally discount the future tax liabilities associated with current bond-financed tax cuts, then tax-debt policies are neutral. Sargent and Wallace (1981) argued that if fiscal policy is constant in a certain sense, then tighter current monetary policy must raise inflation in the future and may even raise inflation now. Both unconventional outcomes hinge on particular assumptions about how future policies respond to expansions in government debt.

Dynamic analysis of macro policies leads to a more fundamental understanding of the inflationary impacts of fiscal policy than is reflected in the Keynesian perspective. The equilibrium price level and inflation rate emerge from the valuation of all assets jointly. By this perspective, current and expected future policies take center stage: it is not meaningful to ask 
about the effects of bigger budget deficits without coupling them with some consistent set of expected policies.

There is plenty of precedent for this topic that predates more recent, formal discussion. Important work includes Friedman (1948, 1960), Brunner and Meltzer (1972, 1993), and Tobin $(1961,1969,1980)$. Aiyagari and Gertler (1985) is a relatively recent important contribution. Sargent and Wallace (1981) lay the foundation for what is now referred to as "the fiscal theory of the price level," that Leeper (1991, 1993), Sims (1994), and Woodford (1994, 1995) develop. The fiscal theory is now part of standard graduate macro curricula [Elmendorf and Mankiw (1999), Ljungqvist and Sargent (2000), Walsh (2002), Woodford (2003)].

Section I describes the asset-pricing perspective on fiscal policy and inflation in broad terms. Section II explains the asset demand functions that emerge from the maximizing portfolio balance model described formally in an appendix. Section III discusses the dynamic linkages among macro policies. Section IV uses the asset demand functions and the dynamic linkages among policies to examine a simple version of the Bush tax cut. That tax cut is treated as a onetime tax reduction financed by sales of new government bonds. As we shall see, even this simple thought experiment is complicated to analyze. Alternative assumptions about how investors expect future policies will adjust to the increased government liabilities deliver very different results for current and future inflation rates.

Several themes run through the paper:

- Any statement about the impacts of monetary (fiscal) policy necessarily carries assumptions about fiscal (monetary) policy behavior.

- Any given monetary (fiscal) policy action can generate a range of responses of current and future inflation, depending on what economic decision makers expect future policies will be.

- Predicting the inflation consequences of a policy action requires specifying all current and expected future monetary and fiscal policies.

Section V applies the theory to address two practical issues tied to U.S. data: the possibility that countercyclical fiscal policies are counterproductive in the sense that they exacerbate and prolong the business cycle; the potential inflation impacts of U.S. demographic changes that imply substantial increases in social security and Medicare expenditures in this century. The paper concludes with a discussion of future directions for research. 


\section{An Asset-Pricing Perspective}

Two key questions arise in dynamic analyses of policy:

1. What are the liabilities of the government in the future?

2. How do reasonable expectations about future policy influence current decisions and the impacts of policy?

These questions are addressed in an environment with an array of assets that includes money, government debt, and capital. One dollar today has purchasing power $1 / P_{t}$, where $P_{t}$ is the current price level. The real return on non-interest-bearing money between today and tomorrow depends on the flow of transactions services it supports and the expected inflation rate, $\pi_{t+1}=P_{t+1} / P_{t}$; the analogous return on bonds is the nominal interest rate, $R_{t}$, adjusted for risk and for expected inflation; the return on real assets is $r_{t}$, adjusted for risk. Arbitrages among money balances, bonds, and investment goods determine their relative values and demands. Expected money growth, tax rates, and government spending directly impinge on these expected rates of return and determine the price level and inflation rate. Only in special and rare circumstances can the arbitrages be separated so that inflation becomes an entirely monetary or entirely fiscal phenomenon. Inflation, therefore, depends generically on all expected future monetary and fiscal policies.

This framework is ubiquitous, applying to all policy analyses. Formal models detail how the policies get transmitted through the economy and specify how expectations are formed. But the general message should not be lost in the details: expected monetary and fiscal policies determine relative rates of return, portfolio choices, current policy options, and the equilibrium that we observe.

\section{Portfolio Choices}

The model, which an appendix formally describes, includes the three ways of carrying a dollar today into the future that section I discusses: money, $M$, government bonds, $B$, and physical capital, $k$. Households and businesses acquire consumption and investment goods by using either money or the transactions services provided by the financial sector. Transactions services include checking accounts, credit cards, money market mutual funds, or any of the 
myriad substitutes for money that the financial sector produces. Transactions services substitute for money in people's portfolios.

Individuals simultaneously choose both the rate of savings out of income and the form in which they hold their wealth. Given their current income, the savings choice also implies their consumption choice. This consumption-savings decision, which is driven by a desire to keep consumption smooth over time, depends on individuals' perceptions of the availability of goods now relative to goods in the future. When future goods are relatively plentiful, individuals increase their current consumption by decreasing savings. But if goods are expected to be relatively scarce in the future, individuals will raise their savings today to cushion their consumption in the future.

Figure 1 illustrates how individuals allocate their wealth among the three assets in their portfolios. The two nominal assets, money and bonds, are substitutes for each other, as indicated by the vertical arrows. In addition, the real asset, capital, substitutes for the nominal assets. Transactions services and money, which play similar roles in acquiring goods, substitute for each other. Government policies, depicted as boxes with rounded corners, have direct effects on the rates of return on the assets. Nominal liability creation - the printing of new money and bondsaffects inflation and the nominal interest rate, which are the returns to the nominal assets. Taxes directly affect the rate of return on capital. Government claims enter the picture through their effects on the government's budget and, therefore, the government's choice of financing. Portfolio choices depend on relative rates of return on the three assets, as well as goods available to the private sector.

In general, asset demands depend on all rates of return and wealth, as Tobin (1969) showed many years ago. For analytical tractability, the formal model suppresses the dependence of the demand for capital on the returns to nominal assets. The model in the appendix delivers an investment decision that can be expressed as:

$$
k_{t}=g\left(\stackrel{(+)}{\eta_{t}} ; \stackrel{(+)}{*}_{t}^{*}\right)
$$

Subscripted variables prevail today (date $t$ ) and unsubscripted variables reflect expected future variables. $y_{t}^{*}$ denotes resources available to the private sector and $\eta_{t}$ denotes what decision makers today expect will be the future paths of tax rates, $\tau$, and government purchases as a share of output, $s^{g}$. Positive and negative signs in parentheses above the function arguments 
report the signs of partial derivatives with respect to the arguments. Specifically, $\eta_{t}$ may be written as $\eta_{t}(\stackrel{(-)}{\tau}, \stackrel{(+)}{g})$, indicating that higher expected taxes reduce $\eta_{t}$, while higher expected government purchases raise $\eta_{t}$. Expression (1) may alternatively be written as

$$
k_{t}=g\left(\stackrel{(-)}{\tau}, \stackrel{(+)}{s^{g}} ; y_{t}^{*}\right)
$$

Higher expected taxes or lower expected government purchases increase current investment.

Interaction between supply and demand for money determines the price level. The money demand decision derived in the appendix is:

$$
\frac{M_{t}}{P_{t}}=h\left(\stackrel{(+)}{\mu_{t}}, \eta_{t} ; y_{t}^{*}\right),
$$

where $\mu_{t}$ reflects today's expectation of the path of money growth, and may be expressed as $\mu_{t}(\stackrel{(-)}{\rho})$, where $\rho$ denotes the growth rate of the money supply in the future. Alternatively, the demand for money is:

$$
\frac{M_{t}}{P_{t}}=h\left(\stackrel{(-)}{\rho} \stackrel{(+)}{\tau,}, \stackrel{(-)}{\tau}, s^{g} ; y_{t}^{*}\right),
$$

reflecting the idea that if individuals expect higher money growth in the future - and hence a lower return to money - demand will decline. The presence of expected tax rates and government purchase shares arises from substitutions between assets: higher expected taxes or lower expected government purchases induce investors to substitute out of capital and into money. This reduces the current price level and inflation rate. Fiscal policy affects inflation by inducing shifts in portfolio choices.

$\mu$ and $\eta$ are policy expectations functions that capture the portfolio balance —or rate-ofreturn - effects of expected policies. They represent what decision makers need to know to form rational expectations over policy. $\mu$ is the marginal value of real money balances and determines the return on nominal assets. Higher expected money growth lowers $\mu$ and induces substitution out of money and into transactions services, raising current inflation.

$\eta$ measures the extent of direct tax financing, which determines the return on real assets. Higher expected taxes (or lower expected government purchase shares) reduce $\eta$ and generate substitution out of real assets into nominal ones, lowering current inflation. 
In this simplified theoretical setting, once current policy choices are known and some position has been taken on what decision makers expect future policies will be, expressions (2) and (4) completely determine current output and inflation, subject to one important caveat.

The caveat is that not all combinations of current and expected future policies are feasible. For example, if the real interest rate exceeds the economy's growth rate, it is not possible for the government to run primary budget deficits - meaning deficits net of interest payments on the debt—-forever. ${ }^{1}$ Such a policy involves the government financing debt service by selling new debt, which will make the path of debt explode. Investors, concluding the government will eventually fail even to meet debt service, will refuse to buy the newly issued bonds, unraveling the financing scheme. The only policies that can occur in equilibrium, therefore, are ones that are consistent with the government's budget constraint now and in the future.

\section{The Government's Budget}

Just like households and businesses, government decisions must satisfy a budget constraint. Unlike private individuals, the government can print money, which generates inflation tax revenues (or seigniorage), and it can levy taxes, which generate direct tax revenues. Total government expenditures consist of purchases of goods and services (including compensation for government employees), transfer payments (including payments to individuals and state and local governments), and debt service (interest payments on outstanding debt). The government has three sources of revenues: direct tax revenues, seigniorage revenues, and any new bond sales above those required to pay off existing debt.

Expenditures and revenues are linked by the government's budget constraint: purchases of goods $/$ services + transfers payments + debt service $=$ tax revenues + seigniorage revenues + net bond sales.

Policy choices must satisfy this constraint every period.

In the absence of debt, government is financed on a pay-as-you-go basis. Each period all expenditures must be matched exactly by tax and seigniorage revenues. Nothing connects today's policies to tomorrow's.

But when there is some government debt outstanding, as has always been the case in the United States, then monetary and fiscal policies are intrinsically linked across time. If current policies change debt, then some future policy must change. Higher debt carries with it higher 
debt service, which is a component of fiscal expenditures. To service the higher debt, some combination of the following adjustments to future policy must occur: higher direct taxes, lower expenditures, or higher inflation taxes. In this sense, current policy choices impose restrictions on which future choices are possible.

The dynamic links also work in the direction from expected policies to current policy choices. Holding expected policies fixed, so future debt service is constant, some current policy must adjust to bring new debt issuances in line with the future debt service. Again, some combination of adjustments now in taxes, spending, or seigniorage must occur to be consistent with the fixed future policies. ${ }^{2}$

The bidirectional linkages among monetary and fiscal policies can be depicted schematically as:

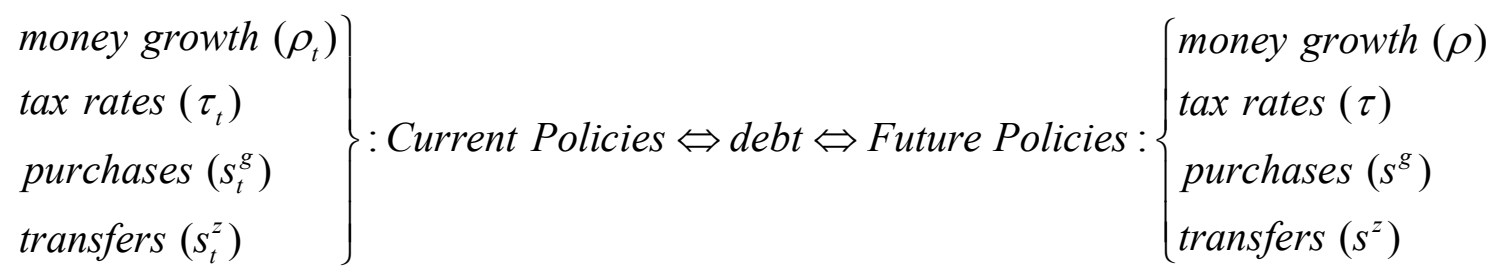

An important implication emerges from the dynamic linkages between monetary and fiscal policies: a complete specification of policy behavior must include a set of current and future policies that are consistent with clearing the government's budget constraint now and in the future. Questions like "What are the effects of higher military spending or lower tax rates?" are ill-posed because they do not specify how other policies will adjust to ensure the budget constraint is satisfied. As the asset demand functions in equations (2) and (4) make plain, the consequences of a change in current fiscal policy for output and inflation depend critically on how decision makers expect future policies will react to any resulting change in the real value of government debt. Until future policies are specified, the best answer is "It depends."

In practical analyses, these dynamic links are often ignored. For example, in its publication The Budget and Economic Outlook, the Congressional Budget Office forecasts the Federal budget deficit under the maintained assumption that current spending and tax policies remain unchanged. Because these assumed policies are almost never feasible, the forecasts the CBO reports can never actually occur. Analogous assumptions are embedded in other government and commercial forecasts. 
In the remainder of this paper I will argue that on both theoretical and empirical grounds it is unappealing to maintain the implausible assumption of unchanged policies.

\section{A Simplified Version of the Bush Tax Cut}

As a first pass at analyzing the consequences of the Bush tax plan, consider a stylized version of the tax cut. There is an initial tax cut at time $t, d \tau_{t}<0$, which is financed by new sales of nominal bonds. Assume that total government claims as a share of output, $s^{g}+s^{z}$, are constant now and in the future. I then derive the inflationary impacts of the tax cut under three alternative specifications of current and future policies that are consistent with equilibrium now and in the future.

Policy 1. Hold current and future money growth fixed at $\left(\rho_{t}, \rho\right)$. This policy fixes the direct return on money $\left(\mu_{t}\right)$ and the nominal interest rate, but it does not fix real money balances unless $\eta_{t}$ is also constant. New debt issued to finance the tax reduction raises the level of debt carried into the future. To clear the government budget constraint in the future, taxes must be expected to rise. But higher taxes reduce the return on capital (lower $\eta$ ) and induce substitution from real to nominal assets, including money. The current price level and inflation rate must fall. This non-Keynesian result that current fiscal expansion reduces inflation runs counter to the prevailing view in the financial press. It stems from links between current and expected taxes created by the expansion of government debt.

Policy 2. Fix both future money growth and future taxes at $(\rho, \tau)$. By assumption, all future policies are constant in the face of the current tax cut, so the burden of adjusting falls entirely on current policies. With no tax increases looming in the future, individuals feel wealthier and increase their spending, driving up the prices of goods today. The price level rises in proportion to the expansion in nominal debt, keeping the real value of debt — and hence future debt service - unchanged. But a higher price level increases the nominal demand for money, so the money supply today must expand passively to meet demand at prevailing prices. ${ }^{3}$ Gordon and Leeper (2002b) label this rather Keynesian outcome "the canonical fiscal theory exercise."4

In this fiscal theory the central bank pegs the nominal interest rate by sacrificing control of the current money stock, which must expand in proportion to the fixed level of real money balances. The adjustments of the current money stock and the price level are governed by fiscal 
needs, which are beyond the central bank's control. This is not "monetization of fiscal deficits" in the conventional sense of printing money to purchase newly issued government debt, as many countries have done during hyperinflations. Instead, the expansion in money is a passive adjustment of the money supply to clear the money market at the prevailing nominal interest rate and price level.

The fiscal theory contrasts with the tax cut policy examined in Policy 1 . That bond-financed tax cut was pure fiscal policy in the sense that it was independent of the path of the money stock. It also reduced nominal spending and the price level. An essential aspect of the fiscal theory is that the current money stock adjusts to clear the money market, raising nominal demand and the price level. If policy authorities were pegging the nominal interest rate and fixing future taxes without reference to anything happening in the economy, the fiscal theory and higher prices are inevitable consequences of a tax cut.

Policy 3. The fiscal authority holds future taxes constant and the central bank fixes current money growth-fixing $\left(\tau, \rho_{t}\right)$. An expansion in current debt can be carried into the future if future money growth rises sufficiently to generate the seigniorage revenues to service the new debt. This raises expected inflation, lowers the expected return on money (lower $\mu$ ), and decreases money demand. With the current money supply unchanged, the price level and current inflation rise to equate supply and demand in the money market. Higher future money growth raises future inflation. It is this higher inflation and seigniorage revenues that service debt in the future. The change in future money growth, of course, depends on the real value of debt in the future, which determines the change in debt service.

This is a case where the fixed net-of-interest fiscal deficits in the future serve to constrain monetary policy to meet fiscal needs. The central bank loses control of the inflation rate in precisely the way Sargent and Wallace (1981) illustrated in their classic "Unpleasant Monetarist Arithmetic" example.

\section{U.S. Fiscal Policy: Present and Future}

Even readers intrigued by the economic logic of the previous arguments, may wonder about their quantitative significance and applicability to practical policy issues. This section aims to alleviate those concerns by applying the model described in sections II-IV to the potential for 
countercyclical policies to be counterproductive and to the inflationary implications of the projected paths of U.S. social security and Medicare expenditures.

\section{Countercyclical Policies}

In variants of the model above, Gordon and Leeper (2000, 2002a) quantify the intertemporal policy impacts emphasized in that setup. Parameters of the model are chosen to match aspects of U.S. data. Time series on U.S. policy variables, $\left\{\rho_{t}, \tau_{t}, s_{t}^{g}, s_{t}^{z}\right\}$, are used to compute perfect foresight versions of the policy expectations functions $\left\{\mu_{t}, \eta_{t}\right\}$. Those expectations functions and current realizations of government purchases $\left(s_{t}^{g}\right)$ are fed into the analytical expressions for investment as a share of output and for the velocity of money. Current and expected policies are the sole source of variation in the exercise: in the absence of changes in policy variables or without significant private responses to policy, investment and velocity would be approximately constant.

Although countercyclical policies arise from both automatic stabilizers and discretionary policy changes, for present purposes nothing rests on the precise mechanism that produces the policies. In terms of current fiscal policies, countercyclical policy is triggered by lower than normal output, and brings forth a lower than normal tax rate and a higher than normal government spending share. Monetary policy responds over the cycle to two factors. First, to accommodate the decline in money demand associated with an economic contraction, the Federal Reserve reduces money growth. Second, to counteract the downturn, the Fed reduces the nominal interest rate by increasing the growth of high-powered money. The net effect is procyclical money growth, which appears in statistical characterizations of the data [see Cooley and Hansen (1995)].

Basic public finance reasoning suggests that countercyclical policies can be counterproductive. Taken together, countercyclical monetary and fiscal policies reduce revenues and increase expenditures during downturns. The resulting increase in future government liabilities implies that some future policy must change. Suppose individuals expect future taxes to rise. This reduces the return on investment (lowers $\eta$ ) and reduces investment and the capital stock. Lower capital reduces GDP, exacerbating and prolonging the downturn. Substitution from real to nominal assets reduces inflation more than it might otherwise fall during the contraction. 
We compute perfect foresight policy paths as a benchmark for specifying expectations. While this represents a limiting case in terms of how much information agents possess about policy realizations, it is agnostic about policy behavior by not assuming policy obeys time-invariant functions. ${ }^{5}$ Moreover, the $\left\{\mu_{t}, \eta_{t}\right\}$ sequences derived from realizations of U.S. policy variables reflect any dynamic interactions of the kind discussed in section III that are embedded in actual policy behavior.

Table 1 compares summary statistics for investment shares and velocity from U.S. data and the model. The model explains $64 \%$ of variation in the level of the investment shares and $30 \%$ at cyclical frequencies. It also accounts for $27 \%$ of the standard deviation of the level of velocity and 50\% at cyclical frequencies. Simulated data are highly persistent and their cyclical components are even more persistent than U.S. data.

These results are startling. All variation in the model stems from realizations of current and expected future macro policies. If policy variables were constant, simulated data would be constant. The cyclical pattern exhibited by simulated data arises from countercyclical policies. With substantial fractions of the variation in portfolio choices attributable to current and expected macro policies, those policies evidently have important quantitative impacts.

\section{Social Security and Medicare}

Combining the gradually aging U.S. workforce with existing provisions for social security and Medicare carries profound implications for future government liabilities. The Congressional Budget Office's (2002) projections for growth in the government's claims on the economy are summarized in Table 2. Future government liabilities are likely to grow substantially, a situation that cannot persist without substantial shifts in other policies. Which policies are expected to change determines the impacts on current and future inflation.

Rising social security, Medicare, and Medicaid expenditures appear as an increase in expected transfer payments, $s^{z}$, in the model. We assume - perhaps unrealistically - that $s^{z}$ cannot be changed, so there will be no reductions in benefits from the social programs. There are two possible responses of policy: hold current policies fixed so that no new debt is carried into the future or adjust current policies so that a lower level of debt is carried into the future. ${ }^{6}$ Each of these requires specifying further adjustments in policies to determine their impacts. ${ }^{7}$ 
If current policies are fixed, then as section III recounted, there is some set of future policies consistent with higher $s^{z}$, given debt inherited from the past. Suppose that future purchases and tax rates are unchanged. Then higher money growth must be expected to raise the revenues needed in the future. Higher money growth $(\rho)$ reduces the value of money balances now (lower $\mu$ ), which induces individuals to substitute out of money. Both current and future inflation rates would have to rise substantially given the magnitudes reported in Table 2. In contrast, if future money growth is fixed, then some combination of lower government purchases, $s^{g}$, and higher tax rates, $\tau$, must be expected to adjust. This policy shifts expected future financing away from inflation taxes and toward income taxes (lower $\eta$ ), reducing the expected return on capital. Individuals substitute out of real assets into nominal ones today. Higher money demand reduces the price level and inflation rate today. Because the capital stock declines, output is lower in the future, which drives up the price level in the future, for a given path of the money stock. Lower inflation today is followed by higher inflation tomorrow.

It may be possible for current policies to adjust sufficiently so that a lower level of debt is carried into the future and future policies do not need to change to accommodate the higher transfer payments. Essentially, this makes some of the outlays on interest expenses in Table 2 available for social security, Medicare, and Medicaid. Reducing debt carried into the future requires some combination today of higher money growth, lower government purchases, lower transfers, or higher taxes. Higher money growth today acts as a lump-sum (non-distorting) tax on nominal assets and the price level rises proportionately. Lower transfers or higher taxes now are also lump-sum and have no impact on the equilibrium (a feature special to this economic model). A cut in purchases, however, frees up resources available to the private sector, which increases money demand and reduces the current price level.

The wide range of possible consequences from projected government transfer payments actually understates the uncertainty surrounding the issue. Policy reforms that seem politically impossible now become increasingly likely as the budgetary consequences are realized. As the political situation evolves in the future, it's likely that some of the future policy adjustment will occur in benefits, so transfers ultimately will rise less than the $\mathrm{CBO}$ now projects. 


\section{Directions for Research}

Exploration of the implications of explicitly modeling dynamic interactions among current and expected future macro policies has just begun. So far the explorations have used stylized economic environments and a limited range of assumptions about how expectations are formed.

How expectations are estimated matters a great deal in this analysis. Perfect foresight represents one extreme [Gordon and Leeper (2000)], while econometric methods that rely entirely on historic correlations to project future policies represent another extreme [Gordon, Leeper and Zha (1998)]. Reality doubtless lies in between. Research suggests Americans have some foresight of fiscal policy [Steigerwald and Stuart (1997)] and analytical work suggests that sorting out the degree of foresight may be important for obtaining good quantitative estimates of monetary and fiscal impacts [Leeper (1989) and Yang (2002)].

There is another aspect of getting accurate assessments of expectations of policy: if policy can shift randomly but infrequently between rules (or "regimes"), then the regime switching should be modeled so expectations of policy incorporate any possible future regime changes. This point was made in the context of the Lucas (1976) critique by Cooley, LeRoy and Raymon (1984). In the context of fiscal policy, Davig (2002a, 2002b) shows that elasticities with respect to tax changes can take a variety of magnitudes and signs, depending on private agents' beliefs about fiscal regime. It is possible to extend the simple assumptions about policy made in the text to allow policies to switch randomly among Policies 1-3. This qualitatively changes the nature of the equilibrium.

How people learn about policy is also likely to be important for accurately determining policy impacts. Sargent (1999) uses a model in which the central bank learns about the nature of the Phillips curve and private agents learn about policy to tell a story about how the United States brought inflation down from its double-digit levels in the late 1970s and early 1980s. He reaches the pessimistic conclusion that a return to the days of high inflation cannot be ruled out. Embedding learning in an environment with nontrivial monetary and fiscal policy interactions could offer a very different, and far richer, interpretation of history.

Empirical work on monetary and fiscal interactions is very much in its infancy. To date the work focuses on trying to isolate particular historical episodes in which Policy 1, 2 or 3 operated, without modeling the probabilities of switching between policy regimes [Cochrane (1999), Woodford (1999), Canzoneri, Cumby and Diba (2001)]. 
All of these extensions amount to different ways to converting "imponderables" into things we can understand and analyze. 
Figure 1. Sketch of Portfolio Choice Model

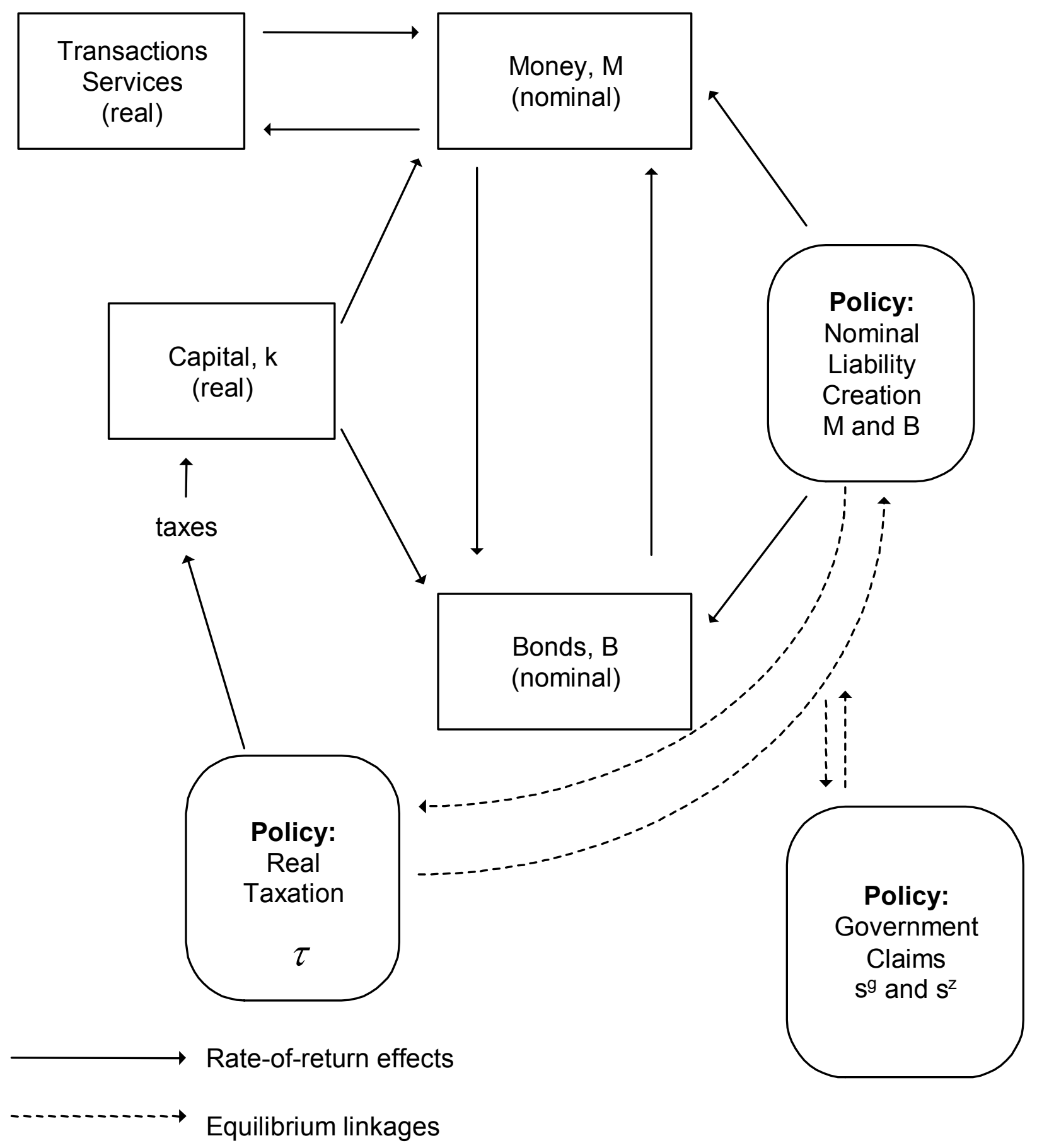


Table 1. Portfolio Choice Statistics

\begin{tabular}{|c|c|c|c|c|}
\hline & $\begin{array}{c}\text { Level } \\
(\mathbf{l o g})\end{array}$ & $\begin{array}{c}\text { Cyclical } \\
\text { Component }\end{array}$ & \\
\hline Variable & $\begin{array}{c}\text { Std. Dev. } \\
(\%)\end{array}$ & $\begin{array}{c}\text { Serial } \\
\text { Correlation }\end{array}$ & $\begin{array}{c}\text { Std. Dev. } \\
(\%)\end{array}$ & $\begin{array}{c}\text { Serial } \\
\text { Correlation }\end{array}$ \\
\hline Investment/Output (Data) & 11.09 & .980 & 3.26 & .775 \\
\hline Investment/Output (Model) & 7.09 & .995 & .96 & .820 \\
\hline Output Velocity (Data) & 29.46 & .998 & 2.57 & .796 \\
\hline Output Velocity (Model) & 8.01 & .995 & 1.26 & .900 \\
\hline
\end{tabular}

Table 2. Federal Outlays as Percentage of GDP

\begin{tabular}{|c|c|c|c|c|}
\hline $\begin{array}{c}\text { Fiscal } \\
\text { Year }\end{array}$ & $\begin{array}{c}\text { Social } \\
\text { Security, } \\
\text { Medicare, } \\
\text { Medicaid }\end{array}$ & $\begin{array}{c}\text { Other } \\
\text { Spending }\end{array}$ & $\begin{array}{c}\text { Interest } \\
\text { Expense }\end{array}$ & Total \\
\hline 2000 & 7.6 & 8.5 & 2.3 & 18.4 \\
\hline 2010 & 8.8 & 7.6 & 0.8 & 17.2 \\
\hline 2020 & 11.3 & 7.1 & -0.5 & 17.9 \\
\hline 2030 & 13.9 & 7.1 & -0.2 & 20.8 \\
\hline 2040 & 15.5 & 7.1 & 1.1 & 23.8 \\
\hline 2050 & 16.7 & 7.1 & 3.1 & 26.9 \\
\hline 2060 & 18.1 & 7.1 & 5.8 & 31.0 \\
\hline 2070 & 20.0 & 7.1 & 9.4 & 36.5 \\
\hline 2075 & 21.1 & 7.1 & 11.5 & 39.7 \\
\hline \multicolumn{5}{|c|}{ Source: Congressional Budget Office (2002) } \\
\hline
\end{tabular}




\section{Endnotes}

${ }^{1}$ If the economy grows at a rate faster than the real interest rate, then it is possible to "grow out of the deficits."

${ }^{2}$ The appendix derives these linkages explicitly in the formal model.

${ }^{3}$ In fact, when future $s^{g}$ and $\tau$ are fixed, the real balance relationship reduces to the conventional one $M_{t} / P_{t}=h\left(R_{t}, y_{t}^{*}\right)$.

${ }^{4}$ See also Leeper (1991), Sims (1994) and Woodford (1995). As Cochrane (2001) observes, the precise result discussed relies on government debt being sold at par. If it sold at a discount instead, the price of bonds may absorb some of the adjustment to equilibrium, offsetting some of the price level impacts.

${ }^{5}$ Perfect foresight is a limiting case of the idea that agents have good information about tax rates and government spending some quarters into the future.

${ }^{6} \mathrm{We}$ do not consider what may be the least politically costly option: ease immigration restriction sufficiently so foreign workers in the United States can finance social security and Medicare.

${ }^{7}$ Auerbach (2002) evaluates the impacts of the tax cut enacted in June 2001 on national savings. His analysis, though quantitative, is similar in spirit to ours in that he considers the implications of alternative expected future policies consistent with equilibrium. He does not derive the implications for the price level and inflation, however. 


\section{Appendix: A Portfolio Choice Model}

The model consists of a representative household, two firms - one producing goods and one producing transactions services - and a government. Gross physical assets of the economy at $t$, $f\left(k_{t-1}\right)$, are allocated to consumption, $c_{t}$, capital, $k_{t}$, and government purchases of goods, $g_{t}$. The aggregate resource constraint is

$$
c_{t}+k_{t}+g_{t}=f\left(k_{t-1}\right) .
$$

We assume capital depreciates completely each period.

Two types of representative firms rent factors of production from households and sell their outputs back to households. The goods producing firm rents $k$ at rental rate $r$ and pays taxes levied against sales of goods to solve

$$
\max D_{G t}=\left(1-\tau_{t}\right) f\left(k_{t-1}\right)-\left(1+r_{t}\right) k_{t-1},
$$

taking the tax rate, $\tau$, and $r$ as given.

Transactions service producing firms rent labor, $l$, from households at wage rate $w$ and sell transactions services, $T(l)$, to households at price $P_{T}$. The function $T(\cdot)$ is strictly increasing, strictly concave, and continuously differentiable. Firms choose $l$ to solve

$$
\max D_{T t}=P_{T t} T\left(l_{t}\right)-w_{t} l_{t},
$$

taking $P_{T}$ and $w$ as given. Both firms behave competitively.

The household owns the firms and receives factor payments, so its income at the beginning of period $t$ is

$$
I_{t}=\left(1+r_{t}\right) k_{t-1}+D_{G t}+w_{t} l_{t}+D_{T t}+z_{t},
$$

where $D_{G}$ and $D_{T}$ are dividends received from the goods-producing and transactions-producing firms and $z_{t} \geq 0$ is lump-sum transfer payments from the government.

Households use money balances and transactions services to acquire goods. Transactions services purchased from the financial sector at time $t$ execute the fraction $T_{t} \in[0,1]$ of private expenditures on goods. Choices of money and services must satisfy the finance constraint:

$$
\underbrace{\frac{M_{t-1}}{P_{t}}}_{\begin{array}{c}
\text { value of } \\
\text { transactions } \\
\text { performed } \\
\text { with money }
\end{array}}+\underbrace{T_{t}\left(c_{t}+k_{t}\right)}_{\begin{array}{c}
\text { value of } \\
\text { transactions } \\
\text { performed } \\
\text { with services }
\end{array}} \geq \underbrace{c_{t}+k_{t}}_{\begin{array}{c}
\text { value of } \\
\text { private } \\
\text { transactions }
\end{array}},
$$


where $M_{t-1}$ is nominal money balances carried into period $t$ and $P_{t}$ is the price level at $t^{2}$ Transactions services may be thought of as a clearinghouse, money market mutual funds, or credit cards, although our specification abstracts from any institutional details. In advanced economies, where most transactions involve the financial sector but do not involve cash directly, $T$ may be close to unity on average. Holding resources devoted to the financial sector fixed, the constraint implies that doubling the value of transactions doubles the value of transactions performed with services by doubling the size of each transaction. It also implies that the marginal product of transactions services increases with the value of transactions performed.

Preferences are defined over consumption and leisure. The current period utility function, $U(\cdot)$, is time-separable, strictly increasing in both arguments, strictly concave, and continuously differentiable. Households are endowed with one unit of time each period and choose $c, k, l, T$, $M$, and $B$, nominal bonds, to solve ${ }^{3}$

$$
\max E_{0} \sum_{t=0}^{\infty} \beta^{t} U\left(c_{t}, 1-l_{t}\right), \quad 0<\beta<1
$$

subject to the budget constraint

$$
c_{t}+k_{t}+\frac{M_{t}+B_{t}}{P_{t}}+P_{t t} T_{t} \leq I_{t}+\frac{M_{t-1}+\left(1+i_{t-1}\right) B_{t-1}}{P_{t}},
$$

and the finance constraint, (A.5), with $0 \leq l_{t} \leq 1, P_{t}, P_{T t}, i_{t}$ and $\tau_{t}$ taken as given, and the initial conditions $\left(k_{-1}>0, M_{-1},\left(1+i_{-1}\right) B_{-1}>0\right)$. Total government expenditures, $g$, are financed by printing money, $M$, and selling nominal bonds, $B$, which pay a net nominal interest rate of $i$, and levying a proportional tax rate, $\tau$, against net output. The government's budget constraint is

$$
\tau_{t} f\left(k_{t-1}\right)+\frac{M_{t}-M_{t-1}}{P_{t}}+\frac{B_{t}-\left(1+i_{t-1}\right) B_{t-1}}{P_{t}}=g_{t}+z_{t}
$$

${ }^{2}$ Including investment goods in the finance constraint, as in Stockman (1981), is substantive. Excluding investment goods implies that the acts of investing or reallocating investments do not generate any demand for money or for transactions services.

${ }^{3}$ One can imagine the representative household composed of a worker/shopper pair. Each member of the household is endowed with a unit of time each period and specializes in the production of a specific commodity. The worker supplies labor inelastically to the goods producing firm and the shopper supplies labor elastically to the transactions services producing firm. The worker's labor supply is unity and the shopper's labor supply is $l$. 
To obtain an explicit characterization of the model's equilibrium, we specialize the model by assuming the following functional forms for the production functions and for preferences:

$$
\begin{gathered}
f\left(k_{t-1}\right)=k_{t-1}^{\sigma}, \quad 0<\sigma \leq 1 \\
T\left(l_{t}\right)=1-\left(1-l_{t}\right)^{\alpha}, \quad \alpha>1 \\
U\left(c_{t}, 1-l_{t}\right)=\ln \left(c_{t}\right)+\gamma \ln \left(1-l_{t}\right), \quad 0<\gamma<\alpha .
\end{gathered}
$$

\section{Equilibrium}

Equating supply and demand for capital yields the solution:

$$
k_{t}=\left(1-\frac{1}{\eta_{t}}\right)\left(1-s_{t}^{g}\right) f\left(k_{t-1}\right)
$$

where

$$
\eta_{t} \equiv E_{t} \sum_{i=0}^{\infty}(\sigma \beta)^{i} d_{i}^{\eta}\left[1-\sigma \beta \frac{\gamma}{\alpha} \cdot \frac{1-\tau_{t+i+1}}{1-s_{t+i+1}^{g}}\right], \quad d_{i}^{\eta}=\prod_{j=0}^{i-1}\left(\frac{1-\tau_{t+j+1}}{1-s_{t+j+1}^{g}}\right), \quad d_{0}^{\eta}=1 .
$$

Equating supply and demand for money yields

$$
\left(1-T_{t}\right)\left[\frac{c_{t}+k_{t}}{c_{t}}-\frac{\gamma}{\alpha}\right]=\frac{\mu_{t}}{\rho_{t}}
$$

where $\rho_{t}=M_{t} / M_{t-1}$ and

$$
\mu_{t} \equiv \beta \frac{\gamma}{\alpha} E_{t} \sum_{i=0}^{\infty} \beta^{i} d_{i}^{\mu}, \quad d_{i}^{\mu} \equiv \prod_{j=0}^{i-1} \frac{1}{\rho_{t+j+1}}, \quad d_{0}^{\mu} \equiv 1 .
$$

This implies equilibrium real balances are

$$
\frac{M_{t}}{P_{t}}=\Delta_{t}\left(1-s_{t}^{g}\right) f\left(k_{t-1}\right),
$$

where

$$
\Delta_{t}=\frac{\mu_{t}}{\eta_{t}-\gamma / \alpha}
$$

\section{Feasible Policies}

Equilibrium requires that current and future policies satisfy the government's budget constraint and that agents' expectations of policy are consistent with equilibrium. This creates interactions among current and future policies. For analytical simplicity, we reduce the analysis to two periods - now and the future - and focus on circumstances in which the economy is in a stationary equilibrium in the future (dates $s>t$ ), but starts from some other position now, at date 
$t$. Fix current and future government spending shares, $\left\{s_{t}^{g}, s_{t}^{z}\right\}$, all $t$, where $s_{t}^{z}=z_{t} / f\left(k_{t-1}\right)$, and assume future money growth and tax rates are constant:

$$
\rho_{t+j}=\rho, \quad \tau_{t+j}=\tau, \quad j>0 .
$$

The government budget constraint can be expressed entirely in terms of current and expected policies. In period $t$ the constraint is

$$
\left[\frac{\rho_{t}-1}{\rho_{t}}+\frac{B_{t}}{M_{t}}-\frac{R_{t-1}}{\rho_{t}} \cdot \frac{B_{t-1}}{M_{t-1}}\right] \Delta_{t}=\frac{s_{t}^{g}+s_{t}^{z}-\tau_{t}}{1-s_{t}^{g}} .
$$

Given expectations of policy embedded in $\Delta_{t}$ and initial government indebtedness as summarizes by $R_{t-1} B_{t-1} / M_{t-1}$, (A.18) reports equilibrium trade-offs among current policies.

We now derive the equilibrium trade-offs among future policies given the state of government indebtedness. Shift the timing of (A.18) forward one period and assume future interest liabilities are correctly anticipated at $t$ by substituting the expression for equilibrium $R_{t}$. Assume the bond-money ratio is constant at $B / M=B_{t} / M_{t}$ in the stationary equilibrium, so there can be no net additions to debt in the future. Reducing the analysis to two periods forces government indebtedness in the future to equal the level inherited from current policies. Dropping the time subscript for variables dated $t+1$ and imposing equilibrium yields

$$
\Delta_{t}=\left[\frac{s^{g}+s^{z}-\tau}{1-s^{g}}\right] \cdot \frac{1}{\left[\left(1-\frac{1}{\beta}\right) \frac{B}{M}+\left(\frac{\rho-1}{\rho}\right)\right]} .
$$

Given government indebtedness carried into the future, as summarized by $B / M,(\mathrm{~A} .19)$ describes the trade-offs among future policies that are consistent with fixed $\Delta_{t}$ being an equilibrium.

Trade-offs between (A.18) and (A.19) determine the interactions between current policies and expectations of future policies. Any change in policy at $t$ that requires a change in $\Delta_{t}$ must be accompanied by a change in policy in the future that is consistent with the new values of $\Delta_{t}$, given the level of government debt $B / M$. 


\section{References}

Aiyagari, S. Rao and Mark Gertler (1985). "The Backing of Government Debt and Monetarism." Journal of Monetary Economics 16, July, 19-44.

Auerbach, Alan J. (2002). "The Bush Tax Cut and National Saving.” Mimeo, Boston University.

Barro, Robert J. (1974). “Are Government Bonds Net Wealth?” Journal of Political Economy 82, November/December, 1095-1117.

Brunner, Karl and Allan H. Meltzer (1972). "Money, Debt, and Economic Activity." Journal of Political Economy 80, September/October, 951-977.

Brunner, Karl and Allan H. Meltzer (1993). Money and the Economy: Issues in Monetary Analysis. (Cambridge, England: Cambridge University Press).

Canzoneri, Matthew B., Robert E. Cumby and Behzad T. Diba (2001). "Is the Price Level Determined by the Needs of Fiscal Solvency?" American Economic Review 91, December, 1221-1238.

Cochrane, John H. (1999). “A Frictionless View of U.S. Inflation.” In NBER Macroeconomics Annual, 1998, Ben S. Bernanke and Julio J. Rotemberg, eds. (Cambridge, MA: MIT Press): 323-384.

Cochrane, John H. (2001). "Long Term Debt and Optimal Policy in the Fiscal Theory of the Price Level.” Econometrica 69, January, 69-116.

Congressional Budget Office (2002). A 125-Year Picture of the Federal Government's Share of the Economy, 1950 to 2075. (Washington, D.C.: CBO).

Cooley, Thomas F. and Gary D. Hansen (1995). "Money and the Business Cycle." In Frontiers of Business Cycle Research, Thomas F. Cooley, ed. (Princeton, NJ: Princeton University Press): 175-216.

Cooley, Thomas F., Stephen F. LeRoy and Neil Raymon (1984). "Econometric Policy Evaluation: Note." American Economic Review 74, June, 467-470.

Davig, Troy (2002a). "Regime-Switching Debt and Taxation." Mimeo, The College of William and Mary.

Davig, Troy (2002b). "Regime-Switching Fiscal Policy in General Equilibrium.” Mimeo, The College of William and Mary.

De Nardi, Mariacristina, Selahattin Imrohoroglu and Thomas J. Sargent (1999). "Projected U.S. Demographics and Social Security." Review of Economic Dynamics 2, July, 575-615.

Elmendorf, Douglas W. and N. Gregory Mankiw (1999). "Government Debt." In Handbook of Macroeconomics, John B. Taylor and Michael Woodford, eds. (Amsterdam: Elsevier Science): 1615-1669.

Friedman, Milton (1948). "A Monetary and Fiscal Framework for Economic Stability.” American Economic Review 38, June, 245-264.

Friedman, Milton (1960). A Program for Monetary Stability. (New York: Fordham University Press).

Gordon, David B. and Eric M. Leeper (2000). "Can Countercyclical Policies Be Counterproductive?" Mimeo, Indiana University.

Gordon, David B. and Eric M. Leeper (2002a). "Notes on the Theory of Countercyclical Policies.” Mimeo, Indiana University.

Gordon, David B. and Eric M. Leeper (2002b). "The Price Level, The Quantity Theory of Money, and the Fiscal Theory of the Price Level." Mimeo, Indiana University. 
Gordon, David B., Eric M. Leeper and Tao Zha (1998). “Trends in Velocity and Policy Expectations." In Carnegie-Rochester Conference Series on Public Policy 49, Bennett T. McCallum and Charles I. Plosser, eds. (Amsterdam: North-Holland): 265-304.

Leeper, Eric M. (1989). "Policy Rules, Information, and Fiscal Effects in a 'Ricardian' Model." Federal Reserve Board, International Finance Discussion Paper No. 360.

Leeper, Eric M. (1991). “Equilibria Under 'Active' and 'Passive' Monetary and Fiscal Policies." Journal of Monetary Economics 27, February, 129-147.

Leeper, Eric M. (1993). "The Policy Tango: Toward a Holistic View of Monetary and Fiscal Effects." Federal Reserve Bank of Atlanta Economic Review 78, 1-27.

Ljungqvist, Lars and Thomas J. Sargent (2000). Recursive Macroeconomic Theory. (Cambridge, MA: MIT Press).

Lucas, Jr., Robert E. (1976). "Econometric Policy Evaluation: A Critique.” In CarnegieRochester Conference Series on Public Policy 1, Karl Brunner and Allan H. Meltzer, eds. (Amsterdam: North-Holland): 104-130.

Sargent, Thomas J. (1999). The Conquest of American Inflation. (Princeton, NJ: Princeton University Press).

Sargent, Thomas J. and Neil Wallace (1981). "Some Unpleasant Monetarist Arithmetic." Federal Reserve Bank of Minneapolis Quarterly Review 5, Fall, 1-17.

Sims, Christopher A. (1994). "A Simple Model for Study of the Determination of the Price Level and the Interaction of Monetary and Fiscal Policy." Economic Theory 4, 381-399.

Steigerwald, Douglas G. and Charles Stuart (1997). "Econometric Estimation of Foresight: Tax Policy and Investment in the United States." Review of Economics and Statistics 79, February, 32-40.

Stockman, Alan C. (1981). "Anticipated Inflation and the Capital Stock in a Cash-in-Advance Economy." Journal of Monetary Economics 8, November, 387-393.

Tobin, James (1961). "Money, Capital, and Other Stores of Value." American Economic Review (Papers and Proceedings) 51, May, 26-37.

Tobin, James (1969). “A General Equilibrium Approach to Monetary Theory.” Journal of Money, Credit and Banking 14, May, 15-29.

Tobin, James (1980). Asset Accumulation and Economic Activity. (Chicago: University of Chicago Press).

Walsh, Carl (2002). Monetary Theory and Policy. Second. (Cambridge, MA, Forthcoming: MIT Press).

Woodford, Michael (1994). "Monetary Policy and Price Level Determinacy in a Cash-inAdvance Economy." Economic Theory 4, 345-380.

Woodford, Michael (1995). "Price-Level Determinacy Without Control of a Monetary Aggregate." In Carnegie-Rochester Conference Series on Public Policy 43, Bennett T. McCallum and Charles I. Plosser, eds. (Amsterdam: North-Holland): 1-46.

Woodford, Michael (1999). "Comment on Cochrane's `A Frictionless View of U.S. Inflation'.” In NBER Macroeconomics Annual, 1998, Ben S. Bernanke and Julio J. Rotemberg, eds. (Cambridge, MA: MIT Press): 390-419.

Woodford, Michael (2003). Interest and Prices: Foundations of a Theory of Monetary Policy. (Princeton, Forthcoming: Princeton University Press).

Yang, Shu-Chun Susan (2002). "Quantifying Tax Effects Under Policy Foresight." Mimeo, Indiana University. 